\title{
Sports Broadcasting
}

\author{
An Accelerator of Business Integration \\ in the Media Industry
}

\author{
Harry Arne Solberg \& Knut Helland
}

\begin{abstract}
The present article analyses how various forms of business integrations, combined with technology innovation, have affected the sports broadcasting market in Norway. Interviews with representatives of Norwegian TV broadcasters and transmission companies documented that extremely fierce competition can motivate former rivals to collaborate. Even the new entrants tend to operate together with others instead of operating autonomously. Such collusion can transfer market power from the sellers to the buyers of sports rights. The interviews showed how product innovations can improve the profitability of sports broadcasting. They confirmed that integration can generate economies of scope advantages (cost reductions from the joint use of inputs), for example by using labour more efficiently within parent companies. Additionally, they also showed that economies of scope advantages can come from similarities in the distribution of goods and services, not only from similarities in the production process.
\end{abstract}

Keywords: sports rights, horizontal integration, vertical integration, congeneric integration, competition, economies of scale and scope advantages

\section{Introduction}

European broadcasting has gone through a revolutionary development since the deregulation in the mid-1980s. The number of stakeholders operating on the supply side has grown, and this has initiated a fierce competition for popular content. Popular sports programmes have played a key role in this matter. The strong price increases on sports rights are a well-known result of this development. Rapid technological innovations have caused a manifold increase in production and transmission capacity. These innovations have also enabled newspapers, mobile phone companies and Internet companies to enter sports broadcasting markets

Parallel with this development, various forms of business integrations have found place in the media industry. We have seen examples of horizontal integration, with former rivals starting to collaborate or even merge, instead of continue to compete. There have also been incidents of vertical integrations, where actors operating at different levels along the sports broadcasting value chain have joined forces.

The present article will investigate the consequences of these integrations, and particularly the role that sports broadcasting has played in this matter. The main research objective is to provide more insight into how various forms of integration, combined 
with technology innovations, have influenced the market conditions. Special attention is paid to factors that have affected competition.

Norwegian sports' broadcasting is deployed as a case. The next section provides a brief account of the producers that have operated on the supply side in Norwegian broadcasting since the early 1990s. After the literature review, we discuss potential advantages and disadvantages of various forms of business integration. This is followed by an empirical section presenting findings from the interviews with representatives of Norwegian broadcasters and transmission companies involved in sports broadcasting. This section also discusses what lessons can be learned. Special attention is paid to issues such as product and technology innovations, competition and the ability to utilize economies of scale and cost advantages.

\section{Norwegian Sports Broadcasting}

The Norwegian Broadcasting Corporation was the single broadcaster in Norway until the deregulation of the broadcasting market late in the 1980s and thus also the only sports broadcaster (NRK). This pattern altered dramatically throughout the 1990s. Commercial TV broadcasters, such as TV2, TV Norge and TV3 entered the scene. Later on, they were followed by pay TV broadcasters, such as Canal Plus and Viasat. These latter actors partly operated in collaboration with transmission companies, such as satellite and cable operators. This growth in entrants increased the competition for popular content, a development that also influenced sports programming. In recent years, newspapers, Internet companies, mobile phone operators, IP television companies, and recently even an energy company have also emerged in the sports broadcasting markets. The consequences of this development are reflected in the values of sports rights fees, and particularly football rights. In 2005, the Norwegian domestic football rights increased almost with $400 \%$ from the former deal (Solberg, Helland \& Ytre-Arne 2007). Since then, however, the pattern has changed. TV companies and transmission companies that at one stage competed fiercely have become more concerned about cost efficiency. This has also moderated the competition. The analytical section will go into detail on these matters.

\section{Literature Review}

The body of literature on the economics of television sports broadcasting has grown considerably in recent years. This involves analyses of the characteristics of sports programmes as commodities (Gaustad 2000), the sale procedures for sports rights (Cowie \& Williams 1997; Solberg 2006a; Andreff \& Bourg 2006), comparisons between the North-American and European markets (Cave \& Crandall 2001; Solberg 2002a; Hoehn \& Lancefield 2003; Szymanski 2006), vertical integrations with TV broadcasters acquiring stakes in sports clubs (Stotlar 2000; Gerrard 2000), regulation of sports broadcasting such as the European Listed Events (Boardman \& Hargreaves-Heap 2000; Solberg 2002b), the demand for TV sports (Forrest, Simmons, \& Burraimo 2006; Hammervold \& Solberg 2006; Solberg \& Hammervold 2004) the broadcasting of international tournaments (Desbordes 2006; Solberg 2006), and the consequences of technological innovations (Turner 1999; Turner \& Shilbury 2006; Turner 2007). See Gratton and Solberg (2007) for a complete overview. 
In recent years, various forms of business integration have been common in the broadcasting industry. This has been paralleled by substantial technological innovations, which have brought about new products as well as new methods of communication. These innovations have affected sports broadcasting, involving both the supply side and the demand side. The number of sports programmes has increased. To some degree, the character of sports programmes has also changed. As a consequence of this, consumption patterns, for example the way in which sports programmes are viewed, have been altered.

These changes have also influenced the strategies of the companies involved in the production and distribution of the programmes. Thus far, these issues have not been addressed in the literature. Therefore, the main objective of the present article is to provide an analysis that contributes to filling these gaps. Special attention is paid to the interaction between technological innovations and business integration processes, and the role sports broadcasting has played in this matter. The next section will discuss the characteristics of alternative forms of business integration.

\section{Theoretical Context}

Figure 1 provides an overview of the actors operating at different levels along the sports broadcasting value chain. Here, sports broadcasting not only covers traditional television broadcasting, but also new communication channels, for example the Internet and mobile telephones. Sports clubs, organizers of sporting events and sports governing bodies are the producers of the contests, i.e. the outputs of the sports production. These outputs represent the inputs for the producers of programmes, whose outputs, in turn, are the inputs of the transmission companies that distribute the programmes to viewers.

Figure 1. The Sport Broadcasting Value Chain

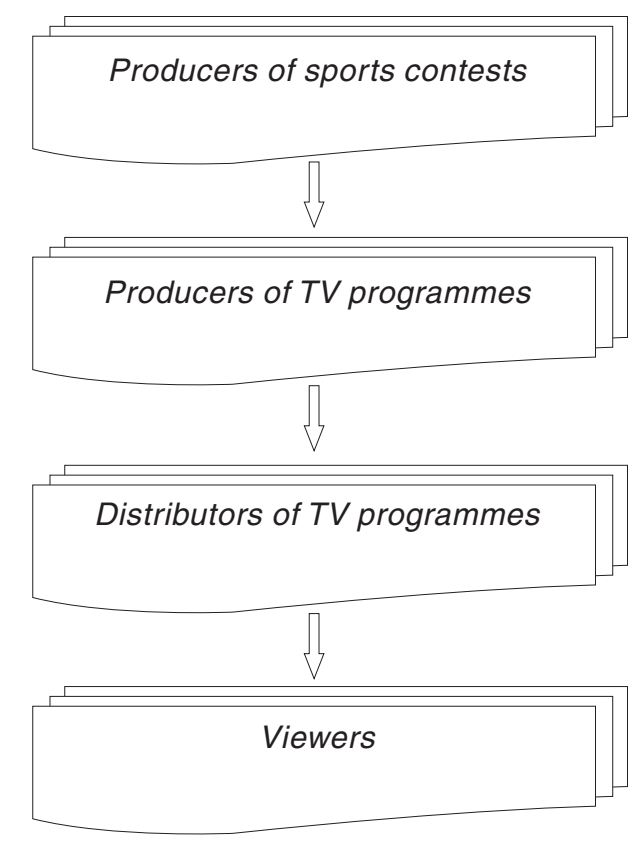


However, the circumstances related to the transfers of inputs and outputs are not static, but a function of a number of dynamic factors. Technological innovations can alter the conditions, for example by increasing the number of products that are related to the core product, which in this case is traditional TV programmes. In addition, they can also affect the way the products are consumed. If new products emerge, and these are complementary to the previous products, they can strengthen the bonds between the producers and the consumers. This, in turn, can make sports broadcasting more profitable, assuming that the producers of the core programmes also are involved in the production and distribution of the new products. In that way, various forms of business integrations can strengthen the market power of the companies involved in sport broadcasting.

\section{Integration}

The media landscape has been characterized by rapid technological innovations during the first years of the $21^{\text {st }}$ century. New products have emerged, and with them also new methods of communication. Many producers have expanded their activities beyond their core area. The borders between activities that previously were separate industries have been dismantled. Many newspapers offer TV features, and even live sports programmes on their websites. Another result of the innovation is mobile viewing. This development has been paralleled by various forms of integration. In this context, we define integration as synonymous with expansion. In principle, a company can expand its activity in four different directions, as Figure 2 illustrates.

Figure 2. Direction of Expansion

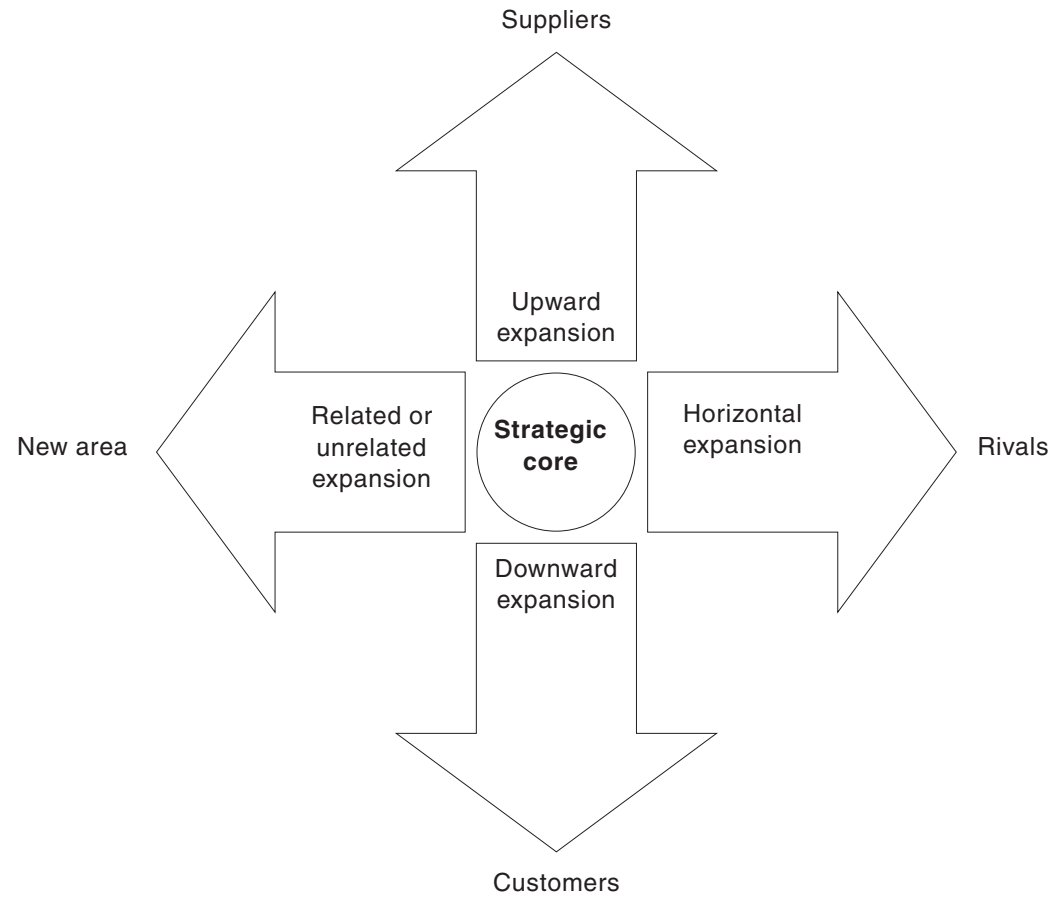


Horizontal integration refers to situations in which producers at the same level along the value chain join forces. Any form of horizontal integration will reduce the competition, and hence increase the market power of the integrated firms in relation to the remaining rivals. This also applies to their positions in relation to their counterparts operating at other levels along the value chain. To what degree this will affect the prices of input and output depends on the reactions from their rivals. If the rivals form a counterattack, this may trigger the competition and further increase the prices. On the contrary, the opposite is likely if the rivals adopt moderate strategies. In general, any producer will benefit if the competition at the other levels along the value chain grows fiercer, as this will increase their own market power.

Vertical integration refers to incidents when a firm or an organization participates in more than one successive stage of the production or distribution of goods or services. Upward (backward) integration is when the firm integrates with suppliers of inputs. Downward (forward) integration is when firms integrate in activities on a level closer to the final customer, for example when a broadcaster acquires stakes in a satellite or cable operator.

Reduced transaction costs represent a potential advantage from vertical integration (Williamson 1979). A firm may chose to perform activities itself rather than rely on the market when transaction costs are likely to be high. Economies of scale advantages can be internalized within the company from combined operations, sharing of activities, and maintenance of a stable throughput in a long stretch of the value chain. It can also reduce inefficiency problems due to asymmetric information between sellers and buyers, a phenomenon that is well known from the principal-agent literature (Douma \& Schreuder 2002).

The values of sports rights can also be affected by vertical integration. Any form of collaboration between mother companies that include producers operating at different levels along the sports broadcasting value chain will reduce the competition, other things being equal. Hence, producers that at one stage competed fiercely may end their rivalry as a result of a combination of horizontal and vertical integration.

Congeneric integration is between producers of goods that are related, but not identical. The producer expands the activity into a related area. Nowadays many media companies are involved in radio and TV broadcasting, the Internet as well as newspapers. Such forms of integration can generate economies of scope advantages, i.e. cost reductions from the joint use of inputs (Gratton \& Solberg 2007). Such cost reductions may come from joint use of inputs such as production facilities, marketing programmes and common administration. The benefits may also include cost savings realized through a reduction of redundant services and personnel.

The benefits of such integration can also come from the production of complementary goods, i.e. goods for which the correlation in demand is positive. It is possible to promote a football match that will be broadcast on a specific TV channel in newspapers, Internet and other TV channels. Additionally, some of those who watch the match on TV may also be interested in reading about it in newspapers and on the Internet after it is finished. Hence, multimedia companies that include various producers, for example TV broadcasters, ratio stations, newspapers, Internet and newspapers, are better able to fulfil such aims than are those operating separately. 
In addition, product innovations can also create new possibilities, e.g. simultaneous consumption.

Unrelated integration refers to a company that expands its activity into an arena that is completely new. The concept "new" normally refers to the final product. However, economies of scope (and scale) advantages can also come from similarities in distribution processes. The case from 2008, when the Norwegian energy company, Lyse Energy, acquired a slice of the Norwegian football rights, which is presented in the empirical section, represents such an example.

\section{The Realization of Integration (expansion)}

In reality a company can expand its activity through any of the following three alternatives:

- Merger and acquisition

- Forming alliances

- New establishment / internal expansion.

This section will discuss some characteristics of the former two alternatives.

\section{Merger and Acquisition}

The potential advantages of merger and acquisition come from synergy effects. Synergy occurs if the interaction between two or more forces results in their combined effect being greater than the sum of their individual effects. In the case of a merger, the synergy effects make the value of a merged company greater than the sum of the value of the two individual companies (Brown 1995).

Financial synergy effects come from reduced capital costs. Firms of a large size can be offered more favourable terms when applying for funding. Larger firms also have more funding and thus can afford heavier investments, for instance in new technology, research and development. In general, they can also take greater risks than smaller firms can. In addition, this may also allow them to afford more expensive sports rights acquisitions than smaller companies can. Moreover, increased operating leverage implies a greater fraction of fixed costs and correspondingly greater business risk, which in itself can require higher capital investment. Operational synergy can come from the sharing of resources and transfer competence. Furthermore, if mergers reduce the competition, this can in turn also reduce the values of rights fees.

\section{Forming Alliances}

Alliances are an alternative when acquisition is blocked, for example by anti-trust regulations. They can generate many of the same economies of scale and economies of scope advantages, as well as other synergy effects, as merger/acquisitions can. Companies that are members of alliances can also transfer competence between each other, which stands in contrast to market solutions, where the firms operate relatively independently. In addition, the possibility to control and influence one another is restricted in market solutions (Meyer 1998) 
Figure 3. Forms of Alliances

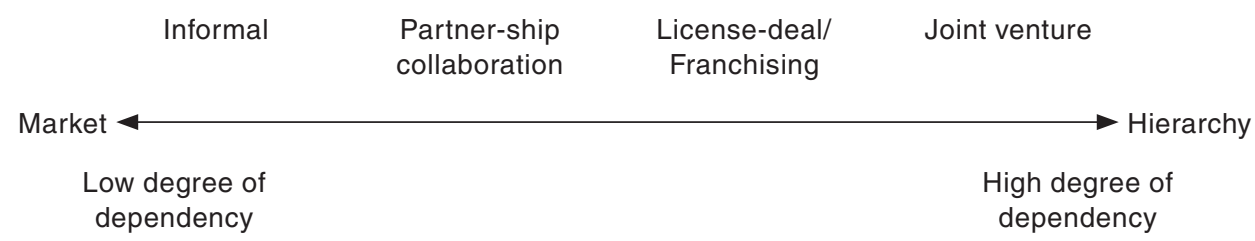

Source: Haugland 2004

Figure 3 shows alternative forms of alliances. In general, alliances are less costly than acquisitions/mergers. Furthermore, members of alliances will be more flexible than merged firms, for example if the market conditions change. It is easier to walk out of an alliance than a merged company. While a merger should be expected to endure permanently, an alliance does not entail the same degree of stability.

\section{Method}

The present article is mainly based on qualitative interviews with leading persons from the sports/media business in Norway: The public service broadcaster NRK; the commercial public service broadcaster TV2; the commercial broadcasters TV Norge and TV3/MTG; the telecommunication company Telenor (which is also the owner of Canal Digital); the satellite TV provider Viasat (Modern Times Group); the energy company Lyse Energy (which operates IP TV on its combined electricity net); and Football Media (the media company of the Norwegian Football Association (NFF) the interviews cover both the supply side and the demand side. ${ }^{1}$

The interviews were semi-structured, and were recorded during two different periods in 2006 and 2008. All the interviews were conducted in personal meetings, except for one, which was a telephone interview. The duration varied between 30 and 90 minutes. The interviews were transcribed in full text, except for one, where the interviewee preferred note taking to recording. The argument was that he or she would be more outspoken if the interview could not be fully documented. However, all the interviewees were open minded and willing to share information with us. The questions were of a character that did not give respondents any incentive to answer strategically. It was our impression that they answered honestly about potential advantages and disadvantages that technological innovations, strategic behaviour and various instruments could have for themselves and their rivals. The same questions were posed to respondents who were directly and indirectly involved in various incidents, and the high degree of correlation in the answers indicates that the answers were trustworthy.

The interviews have had a double function: First, they are the main basis for our analyses, and second, they have at the same time been important for our background knowledge of the field. Analytically, the interviews have contributed to our overall analysis in illustrating how different actors think strategically about alliances related to their own activities. In addition to the interviews, some background information was also extracted from relevant news channels and documents. ${ }^{2}$ By using this kind 
of material, we could also conduct a validity check regarding the contributions of the interviewees.

\section{Analysis}

This section will present and analyse the results from the interviews. The first part concentrates on competition strategies of commercial broadcasters, also the prioritizing of attractive products. Further we focus on the matter of integration and collaboration, another subject that has affected the competition. Then we take the subject of integration and expansion a little further, and discuss the consequences of collaboration on competition. The last part focuses on the possibility to exploit economies of scale and economies of scope advantages.

\section{Competition Strategies}

The deregulation of European broadcasting paved the way for new entrants, involving both broadcasters and transmission companies. Popular sports immediately became an effective instrument in the battle to recruit viewers and subscribers. This increased the competition for popular sports content, and in turn also the values of sports rights. In his book about the sale of the Norwegian football rights in 2005, sports editor of TV2 (the Norwegian commercial public service broadcaster), Bjørn Taalesen, points out that this incident involved something more than just a fight for some football rights. The main concern was the possibility to dominate the future digital TV market in Norway.

Football had become the instrument to obtain a strategic position and decide the premises for development of the pay TV market everybody knows will come... Football was regarded as the instrument with which to win this market. It is belief about its interest, combined with the fact that there is a willingness to pay, that initiates such efforts. Nevertheless, this is also a strategic investment for a TV future, where one has to wait ten years to decide whether or not it was madness... (Taalesen 2006: 97).

It was not just a fight about football rights, but a fight about the future Nordic TV market. Norwegian football was just the arena for this fight. Head of sports rights in NRK, Tor Aune, expressed similar ideas in the interview. According to him, the competition for sports rights has played a major role in upholding the war between Canal Digital ${ }^{3}$ and Modern Times Group ${ }^{4}$ (MTG). The interviews confirmed that the seller has tried to take advantage of this situation, not only by orchestrating bidding wars between individual TV broadcasters, but also by stimulating collaborations in order to make them more powerful in the competition. Taalesen (TV2) admitted that Rune Hauge, the agent representing the Norwegian Football Association (NFF), encouraged the bidders to form alliances. His aim was to create a bidding war between strong units. MTG had their Viasat distribution platform (satellite), while Telenor had Canal Digital (cable and satellite). These were the major rivals in the decisive fight over the future digital TV customers (Taalesen TV2). The collaboration between Viasat and Canal Digital will be discussed more thoroughly later on, as will the subject of integration between bidders in general. 


\section{The menu of sports programmes}

The interview with Taalesen indicates that commercial broadcasters have preferences for multiproduct packages lasting over a long period, for example club football tournaments. Those who succeed in acquiring such packages can even tolerate playing second fiddle for shorter periods. As an example, TV2 said no to broadcasting the Olympic Games, even though their membership in the European Broadcasting Union (EBU) gave them the possibility:

16 days of happiness for that price is too costly. It gives no profit. The fact that we would have to share it with NRK makes it uninteresting. We would not spend the same amount on the Beijing Olympics as NRK. We will suffer during the 2010 Vancouver, Winter Olympics in February. Therefore we will not spend any additional money on programme activities during these fourteen days. However, except for that, we will do well (Taalesen TV2).

This strategy corresponds with the policy of BSkyB, the most successful European pay TV broadcaster in recent years. They have shown moderate interest in on-off events and did not even bid on the 2002 and 2006 FIFA World Cup. Another reason for this is the Listed Events regulation, which prevents pay TV channels from broadcasting such events exclusively (Solberg 2002b).

Taalesen points out that Sundays and Mondays are the best broadcasting time for football and also what gives them commercial value:

Everybody knows that there is football on TV on Sunday, also the advertisers. If they don't know it - they will learn it. To have a football match 26 Sundays is much more important than the number of viewers who watch the cup final. The cup final is in itself not interesting (Taalesen, TV2).

Here it becomes clear how important routines are, not only for viewers, but for advertisers as well. When Sunday has become integrated as a day to watch football in people's minds, it stays that way, and it gives a form of stability for the advertisement business.

In addition to football matches, the revenues from daily sports news programmes are also extremely important for commercial broadcasters. The programmes with the highest commercial value are, according to Taalesen, the sports news at 21.25. The commercial break between the weather news and the sports news is the one generating the highest advertising revenues. It attracts 500,000-600,000 viewers every day, and is much more important than anything else.

Additionally, the first years of the $21^{\text {st }}$ century have brought about technological innovations, which in turn have created new products as well as new methods of communication. Furthermore, these innovations have partly removed the borders between media activities that previously were separated, for example between TV broadcasters and newspapers. Nord from Canal Digital emphasizes the role sports is playing in testing new services. He says: "A service will not receive attention unless you have something that makes people willing to spend time on the new technology" (Boge 2009). Taalesen puts it like this: "Sports is a driving force. You need "leading cars", and here, sports is often the leading car. There is willingness to pay for watching (sports) and new technology is common. Technological innovations have not only increased the number of products, but also enabled the integrated media companies to communicate with con- 
sumers simultaneously through several communication channels. This, as an example, also involves interactive communication during live programmes. Sports is what drives many of our internal projects forward" (Taalesen, TV2). He explains how one can use a TV programme to create new activity on the Internet.

It starts with text messages to elect the best player. Then you develop it so that you can make substantial revenues from creating a manager game on Tour de France, where the viewers are engaged to "join" the programme.

The best case scenario for the broadcaster is, according to Taalesen, when viewers watch $\mathrm{TV}$ and are communicating about it on the Internet at the same time. The sports editor sees great possibilities in the new form of interactivity, and appreciates how quickly the development is moving forward:

I have spent more time the last year on the Internet than on TV, as a TV sports editor. This illustrates the direction of the development. I believe the values of sports rights have reached a level where you have to "secure" the value chain on all platforms involved in this activity. The time when you could do something on TV that not is coordinated on the Internet has come to an end (Taalesen TV2).

Nord also appreciates the new development, and points out the possibility of generating revenues in many different ways as an advantage to which football is privileged. The opportunities are many, according to the managing director: advertising, mini-pay and premium, which is an expensive subscription. By offering some tasty stuff on expensive subscription to those who are very interested, and some stuff to those who are somewhere in between on mini-pay, you exploit money from different market segments, he points out. Even though the problem of overlapping can occur, so that different resources reduce each other, according to Nord this is a surprisingly small problem.

However, successful innovations require that customers be familiar with the new products and services. The interviews documented that sports has played an important role in this matter, by teaching viewers how to apply new technology and facilities. Taalesen's statements confirmed the complementary relationship between traditional TV viewing and Internet. They also indicate how integrated media companies can benefit from joint production of complementary products. This explains why the profitability of sport rights acquisitions cannot be measured only on the basis of direct revenues and costs. Although the total direct costs (right fees and the programming costs) can exceed the direct revenues, the acquisitions can nevertheless be profitable for multi-firm companies, assuming the revenues from related activities are absorbed by the company. In the literature, this is known as pecuniary externalities. Various forms of integrations can internalize such impacts. The objective of fully integrated firms is to maximize the profit of the entire company, not the specific firms or separate activities.

\section{Business integration in the Norwegian market}

The competition for viewers was a driving force in Norwegian sports broadcasting the years following the deregulation of European (and Norwegian) broadcasting. During the first decade of the $21^{\text {st }}$ century, however, we have seen indications of reduced competition. On several occasions, former rivals have chosen collaboration instead of competition. Incidents of horizontal and vertical integration, as well as combinations of 
these two alternatives, have been observed. This turnaround has moderated price growth. According to the interviewees, the strong inflation on right fees has in itself initiated such collaboration. They also indicated that expensive rights have motivated broadcasters to look for alternative products. This illustrates that being extremely successful on a short-term basis can also have a down side in the long run.

According to Erik Nord, Managing Director of Telenor Media and Content Services, this is particularly a problem now when the football association has demanded a very high price, which they cannot meet. Then their reply has been to turn around and look for other revenue sources:

The first thing we have done is to make an agreement with Viasat (satellite distributor), which gives us Champions League on our channel. There are many good international sports rights on the market, i.e. that you can buy on short notice. Since TV2 is able to promote them, this can be a good solution. We are open for discussions with the Football Association, but not at any price (Nord, Canal Digital).

Before discussing the consequences of such collaborations, we will take a look at a particular example.

\section{Buyer Collaboration: The Case of Viasat and Canal Digital}

The interviews confirmed that collusion has become more common in the broadcasting market compared to a few years ago, and that expensive sports right have played an important role in this matter. Aune points out: "there is no doubt that it is sports that have driven forward the alliance" (Aune, NRK). Alliances are being established instead of participating in bidding wars. Taalesen felt that Viasat did not bid on Norwegian football rights since they have channel swop with Canal Digital. This refers to an agreement under which both satellite platforms should have the five most popular channels. "Everybody who buys Viasat also gets TV2's matches. Why should they then spend so much money in it? They already have the Champions League. Regardless of whether I bid on it, they will get it" (Taalesen, TV2).

This corresponded with the view of Nord, who also expressed reluctance to participate in bidding wars: "The swop between Viasat and Canal Digital gives Viasat admission to Norwegian football without having to pay for it, and we (Canal Digital) get admittance to Champions League without having to pay for it" (Nord, Canal Digital).

These reflections illustrate some of the benefits vertical integration can have for actors operating along the sports broadcasting value chain, as discussed in the theoretical section above. Upward integration can secure delivery of (more) input, while downward integration can secure distribution of (more) output. Additionally, the integrated firms will also become more powerful in the competition with rivals. This, in turn, can initiate further integrations by rivals.

Integration can also enable broadcasters to reach more viewers than if they were to operate alone. When TV2 only had a free-to-air channel, they refrained from bidding on sports rights that best suited to pay TV, according to Nord. Likewise, Canal Digital, who only had pay TV, did not bid on sports rights best suited to free-to-air TV.

It was not a forced marriage, but how do you compete with a full vertically integrated rival? Yes, you have to collaborate. ... NRK started to collaborate with

Modern Times Group (the mother company of Viasat), and that triggered the 
owners of Telenor (mother company of Canal Digital) and TV2. TV2 was afraid of losing their position (Nord, Canal Digital).

This particular example illustrates how the competition for sports rights can initiate collaboration, which in turn can affect the competition.

The interviews also confirmed that buyer collusion had affected the sellers of sports rights. Knut Kristvang, managing director of Football Media, emphasized this matter by pointing out how TV2 was long transmitted exclusively on Canal Digital, but is now also on Viasat. And the other way around, TV3 and Viasat 4 (both owned by Viasat) are now shown on Canal Digital. This is due to the agreement between the two satellite platforms according to which both should show the top five channels. Such deals between the two platforms also eliminate the possibility of creating any bidding war between them. According to Kristvang, this is what ended the competition between the platforms.

As the theoretical section illustrated, collaborations can take alternative forms. It takes less to form an alliance than to merge with former rivals or to establish a new firm. On the other hand, alliances and similar collaborations may be unstable. As Kristvang pointed out: "Alliances are often established in the $12^{\text {th }}$ hour, shortly before the bids are submitted. This makes it difficult to predict them" (Kristvang, NFF).

According to Aune, the MTG/NRK alliance does not have the same degree of stability as the collaboration between Canal Digital and TV2. The latter is more ad-hoc based, because they found each other during the last negotiations (the sale of Norwegian football in 2005), thus they have a "partner agreement" when it comes to the collaboration:

They can show replays of sports that we have admittance to, which they don't have since they are not members of the European Broadcasting Union (EBU). We, on the other hand, can have admittance to the World Ice Hockey Championship, the German Bundesliga in football, golf and other sports that we don't have. It is a balanced "terms of trade". It is difficult to predict the duration on the current alliances (Aune, NRK).

The unpredictability of the alliances is, as Aune says, especially connected to their duration. How long they will last depends on how the channels plan their future. The collaborations have involved all forms of integration, i.e. horizontal, vertical, congeneric, and even non-related integration. Horizontal integration has affected the competition both between the producers and distributors of sports programmes.

The consequences of buyer collaboration have been reflected in the market. When the Norwegian football rights were sold in 2005 , the fees increased by about $400 \%$ from the former deal. The major reason for this was the extremely fierce competition between three rivalling bidders. This was different in 2008, when some former rivals had started to collaborate. Even though new entrants, such as newspapers and an energy company, also entered the market, the fees hardly increased when adjusted to the extension of the league from 14 to 16 teams.

In the long run, collaborations that make bidders more powerful in one specific auction represent a two-edged sword for the owners of sports rights. TV broadcasting and related activities have typical economies of scale characteristics, with high entrance costs and (relatively) low variable costs (Gratton \& Solberg 2007; Gaustad 2000). As a consequence of this cost structure, the natural market form will be some variant of oligopoly, i.e. with a few producers operating on the supply side in relation to viewers. This is of 
importance to the distribution of power between the buyers and sellers of sports rights. The distance to a monopoly (or monopsony) is short. Thus, if former rivals decide to join forces instead of continuing to compete, this may have dramatic consequences for the competition, and hence also for prices. The fewer broadcasters that originally were present, the closer a reduction can move the market towards a monopsony (one single buyer). This, in turn, will transfer market power from the sellers to the buyers. Hence, encouraging bidders to collaborate is a risky strategy for the owners of sports rights. Even though the revenues can increase immediately, the long-term effects can be negative if the competition is significantly reduced.

The interviews illustrated a potential down side for the sellers in case auctions become "too" successful. Sports rights auctions are staged regularly, and with some few exceptions, the potential bidders tend to be the same. The history has many incidents of the winner's curse, which is a situation where the winner of an auction is worse off as a consequence of overestimating the value of item and thereby bidding too much. Such experiences can motivate the bidders to adopt more moderate strategies next time sports rights are for sale. Some might decide to withdraw from the market. It can also encourage collaboration as an alternative to fierce competition.

In an English (open) auction, all bidders will have full information. The winner will submit a bid slightly above the second highest bid. Thus, it is the gap between the highest and second highest bid that determines the final price (Solberg 2006). Although the seller formally stages a secret auction, history reveals many incidents of information leakage. The experiences from Norway illustrate the difficulties of harvesting the maximum revenue potential if the competition is reduced.

Similar experiences have been observed in other markets. During recent years in Japan, the intensively collusive market has led to reduced fees for all the top European leagues, including the English Premier League, the Italian Serie A, the Spanish Primera Liga and the German Bundesliga (TV Sports Markets 2009a) . Over the years, BSkyB has adopted a dominant position in the UK TV market, involving both the production and distribution of processes. The fact that their mother company, News Corporation, is involved at several stages along the sports broadcasting value chain has reduced their motives to compete. According to interviews in the press, some observers believe the hard core competition may be over. In 2009, ESPN, which is a member of the Disney company, took over the rights for the English Premier League from Setanta (an Irish-based media company). However, the fact that ESPN and BSkyB formally are rivals has not triggered the competition (by 2010). As one observer claims: "Where BSkyB and ESPN can collude, they certainly will”" (TV Sports Markets 2009b) ${ }^{6}$. ESPN is distributed on BSkyB's Sky Digital platform, therefore BSkyB will handle the production of ESPN's live coverage of English Premier League Matches. This, of course, reduces the motives to compete. Indeed, some observers have argued that BSkyB's vertically integrated model is the main reason why there is no competition in the UK (TV Sports Markets 2009c) ${ }^{7}$

\section{The Exploitation of Economies of Scale and Scope Advantages}

The combination of technological innovations and integrations has also enabled broadcasters and transmission companies to improve cost efficiency. This, as an example applied to the use of labour, according to the interviews. "It is synergy and full integration, 
which also is about using all platforms", Taalesen explains it and makes the occupation of writing as his example. The way journalists worked until recently, by bringing along a photographer, travelled far away to find a place to send the pictures from, spent substantial time in editing and also making it nice, and finally went home, is about to disappear according to the sports editor:

In the future he will have to bring the camera himself and take pictures that can be sent immediately by email from wherever he is. Then he has to write a story for the Internet, together with the pictures. Back at work, he must look for alternative angles on the same story, to be presented on TV some hours later. This is in a way the difference. Integration on the Internet also means integrating labour. The employees have to do several jobs and have to work on all platforms (Taalesen, TV2).

The technological innovation opens up a whole new way of working. It is not as simple as it used to be, because the employee has to be everywhere at the same time. What used to be one job suddenly becomes several jobs.

The interviews also confirmed that the initial owners of sports rights, i.e. the sellers, understood the value of being on all platforms, not only on TV. Kristvang, for example, emphasized that they would use the platforms that the general public uses, i.e TV, the Internet, mobile phones, radio and other things that might emerge. "They will be used so that football upholds its popular position, and hence to finance Norwegian football" he said (Kristvang, NFF).

Innovation processes often involve "trial and error" experiences, and the interviews confirmed that sports broadcasting was no exception. Nord from Canal Digital tried motorsport, Formula One with advanced technology, such as putting the camera on the driver, but that did not succeed, except for in Finland.

The integration process has also been driven forward by other economies of scale and economies of scope advantages based on similarities in the distribution process. This was illustrated when Lyse Energy acquired a slice of the Norwegian football rights for 2009-2012. Lyse Energy was originally an energy company that had no experience of sports broadcasting. Thus, their acquisition of football rights in 2008 was a big surprise to everybody.

Their motivation to expand their activity to a new area was related to the prospect of exploiting economies of scope advantages - not based on similarities in products, but on similarities in the distribution of products. When the new energy law came into force in 1990 , the company predicted that the future competition would require the costs to be distributed on a larger customer base. Their communication director, Grethe Høiland, explained the rationale behind their expansion into a new market:

We started to look at the possibility of utilizing our strength: To build out infrastructure, and also use it on other products than energy. What do we find in our ditches? We find communication cables and electricity cables. The idea has been to put as much as possible in one ditch, as much as possible in one cable, and as much as possible on one invoice. We have experience with large customer bases. We also have experience with digging and establishing distribution infrastructure, as well as the processes related to these activities. That was the background (for why Lyse Energy invested in football rights). The strategy - "everything in one 
ditch, everything in one cable, and everything on one invoice", it emerged after some time. First and foremost, we aimed to be a distributor (Høiland, Lyse Energy).

In general, economies of scope advantages refer to reduction in costs owing to the production of similar goods. This enables producers to use inputs in the production of several goods. The average total cost of production decreases as a result of increasing the number of different goods produced. The example of Lyse Energy is interesting, as it illustrates that such advantages can also come from the joint distribution of goods, not only from joint production of them. In this case, the nature of the goods (electricity and TV programmes) was totally different.

\section{Conclusion}

The first years following the deregulation of European broadcasting, a number of commercial broadcasters entered the markets. This added fuel to a fierce competition for popular content, and the strong increase in sports rights is one of the results of this development. Since then, we have seen signs of a reduction in competition. Although some rights fees have continued to increase, the growth has been more moderate than the first years after deregulation. On some occasions, rights fees have even been reduced. One reason for this is the collaboration between buyers of sports rights. Instead of participating in bidding wars, former rivals have established alliances or other forms of collaboration. Companies involved in the production and distribution of programmes have preferred collaboration when the competition has grown too fierce. This has applied to both TV channels and transmission companies, as the interviews with representatives of Norwegian media firms have confirmed.

Broadcasting has been characterized by rapid technological innovations during the first years of the $21^{\text {st }}$ century. New communication channels have emerged, while product innovations have brought about new products. Consumption patterns have changed. It seems likely that this development will continue. The borders between media activities that previously were separated have been more or less removed. Using the Internet and mobile telephone as a supplement to traditional TV viewing is now very common. The interviews documented how sports broadcasting has had an important role in this development, for example by familiarizing viewers with the new products and services. They also indicated that product innovations per se have made integration more advantageous. One such example is the ability to engage in interactive viewing, where viewers watch $\mathrm{TV}$ and at the same time are active on the Internet. This illustrates how TV broadcasters can benefit from also having control over the production of goods and services that are complementary to TV programmes. Expansion of the product flora itself is a motivation for integration. Joint production of complementary products can increase profit, given the right circumstances.

The technological innovations that have characterized the broadcasting markets during the first years of this century are likely to continue. The result if this process will be new products. The character of the existing products may also be affected. This, in turn, will complicate the job of predicting the revenues of the flora of sports programmes. It will also affect the competition and distribution of market power between the companies involved on the supply side and the demand side. These conditions, with regard to 
which rapid change is a well-known characteristic, also illustrate the need for further research on these issues.

\section{Notes}

1. NRK: Tor Aune (Head of sports Rights), Øyvind Lund (Sports Editor). TV 2: Bjørn Taalesen (Sports editor). TV Norge: Morten Aass (Managing Director) and Hallbjørn Saunes (News Editor). TV 3/Viasat/ MTG: Stian Kleppo (Sports-director. Telenor: Petter Svendsen (Sponsor Director), Erik Nord (Managing Director, Telenor Media and Content Services). Lyse Energi: Grethe Høiland (Market Director). Fotball Media: Knut Kristvang (Managing Director).

2. As the Norwegian www.kampanje.com

3. A transmission company involved in both satellite, terrestrial and cable transmission.

4. A media company owning free-to-air channels, pay TV channels, which is also involved in satellite transmission.

5. TV Sports Markets, 2009, Vol. 13, no 8.

6. TV Sports Markets, 2009, Vol. 13, no 12.

7. TV Sports Markets 2009, Vol. 13, no 14.

\section{References}

Andreff, W. \& Bourg, J-F. (2006) 'Broadcasting Rights and the Competition in European football', in C. Jeanrenaud \& S. Kèsenne, (eds.) The Economics of Sport and the Media. Cheltenham, UK: Edward Elgar.

Boardman, A.E. \& Hargreaves-Heap, S.P. (1999) 'Network Externalities and Government Restrictions on Satellite Broadcasting of Key Sporting Events', Journal of Cultural Economics 23, 167-181.

Boge, E. (2009) Konvergens, sportsrettigheter og formidling - En casestudie av Telenors utnyttelse av fotballavtalen 2005. [Convergence, sports rights and distribution. A case study of Telenor's exploitation of footaballa agreement 2005.] Master thesis, University of Bergen, Department of Information and Media Science.

Brown, W.S. (1995) Principles of Economics, St. Paul, MN: West Publishing Company.

Cave, M. \& Crandall, R. (2001) Sports Rights and the Broadcast Industry. The Economic Journal, 111 (February), F4-26.

Cowie, C. \& Williams, M. (1997) 'The Economics of Sports Rights', Telecommunications Policy. 21, 619-634.

Desbordes, M. (2006) 'The Relationship between Sport and Television: The Case of TF1 and the 2002 Football World Cup', in C. Jeanrenaud \& S. Kèsenne, (eds.) The Economics of Sport and the Media. Cheltenham, UK: Edward Elgar.

Douma, S. \& Schreuder H. (2002) Economic Approaches to Organizations. Third edition. Essex, UK: Pearson Education Limited.

Forrest, D., Simmons, R., Buraimo, B. (2006) 'Broadcaster and Audience Demand for Premier League Football', in C. Jeanrenaud \& S. Kèsenne (eds.) The Economics of Sport and the Media. Cheltenham, UK: Edward Elgar.

Gaustad, T. (2000) 'The Economics of Sports Programming', Nordicom Review, 21(2), Special Issue, 101-113.

Gerrard, B. (2000) 'Media Ownership of Pro Sports Teams: Who Are the Winners and Losers?', Sports Marketing \& Sponsorship, 2, 199-218.

Gratton, C. \& Solberg, H.A. (2007) The Economics of Sport Broadcasting. London: Routledge.

Hammervold, R. \& Solberg, H.A. (2006) TV Sports Programmes - Who is Willing to Pay to Watch? Journal of Media Economics 19, 147-162.

Haugland, S.A. (2004) Samarbeid, allianser og nettverk [Cooperation, alliances and networks], second edition, Oslo: Norwegian University Press.

Hoehn, T. \& Lancefield, D. (2003) Broadcasting and Sport. Oxford Review of Economic Policy 19, 552-568.

Meyer, C.B. (1998) 'Strategiske veivalg og motiver for fusjoner og oppkjøp' [Strategic choice of direction and motives for mergers and acquisitions], in K. Boye and C.B. Meyer (ed.), Fusjoner og oppkjøp [ Mergers and acquisitions] Oslo: Akademisk Forlag.

Solberg, H.A. (2002a) 'The Economics of Television Sports Rights. Europe and the US - A Comparative Analysis', Norsk Medietidskrift, 10(2), 59-81.

Solberg, H.A. (2002b) 'Cultural Prescription - The European Commission's Listed Events Regulation - Over Reaction?', Culture, Sport, Society. 5(2), 1-28.

Solberg, H.A. (2006a) 'The Auctioning of TV Sports Rights', International Journal of Sports Finance, 1, $33-45$. 
Solberg, H.A. (2006b) 'International TV-sports Rights - Risky Investments', in C. Jeanrenaud \& S. Kesénne (eds.) The Economics of Sport and the Media. Cheltenham, UK: Edward Elgar.

Solberg, H.A. \& Gratton, C. (2004) 'Would European Soccer Clubs Benefit from Playing in a Super League?', Soccer and Society, 5(1), 61-81.

Solberg, H.A., \& Hammervold, R. (2004) 'Sport Broadcasting - How to Maximize the Rating Figures.', Trends in Communication, 12(2/3), 83-100.

Solberg, H.A., Helland, K., \& Ytre-Arne, B. (2007) 'Integration between Broadcasters and Transmission Companies Involved in Sports Broadcasting', in Dave Arthur and Simon Chadwick (eds.). International Cases in the Business of Sport. Elsevier.

Stotlar, D.K. (2000) 'Vertical Integration in Sport', Journal of Sport Management, 14(1), 1-7.

Szymanski, S. (2006) 'Why Have Premium Sports Rights Migrated to Pay-TV in Europe but not in the US?', in C. Jeanrenaud \& S. Kèsenne (eds.) The Economics of Sport and the Media. Cheltenham, UK: Edward Elgar.

Turner, P, (1999) 'Television and Internet Convergence: Implications for Sport Broadcasting', Sport Marketing Quarterly, 8, 43-49.

Turner, P. (2007) 'The Impact of Technology on the Supply of Sport Broadcasting', European Sport Management Quarterly 7 (4).

Turner, P. \& Shilbury, D. (2006) 'Broadcasting Technology and Its Influence on Sport Broadcaster Interorganisational Relationship (IOR) Formation', International Journal of Sport Management and Marketing, Special Issue (Interorganisational Relationships).

Taalesen, B. (2006) Milliardspillet. Kampen mellom TV 2 og NRK om TV-fotballen - sett fra innsiden. [The billion game. The fight between TV2 and NRK about the TV football - as seen from the inside] Oslo: Damm.

Williamson, O.E. (1979) 'Transaction-Cost Economics: The Governance of Contractual Relations', Journal of Law and Economics, 22, 233-261.

HARRY ARNE SOLBERG, Dr.philos., Professor, Trondheim Business School, Sør-Trøndelag University College, Trondheim, harry.solberg@hist.no

KNUT HELLAND, Ph.D., Professor, Department of Information Sciences and Media Studies, University of Bergen, knut.helland@infomedia.uib.no 